\title{
Marks of Capital: Colonialism and the Sweepers of Delhi ${ }^{1}$
}

\author{
VIJAY PRASHAD
}

Summary: In a sub-field of Marxism, A.G. Frank and E. Laclau debated the intricate details of Frank's critique of the "dualist thesis". That thesis argued that capitalism failed to overcome feudalism in its colonial adventure; Frank argued that to posit the duality between capital and feudal forms does violence to the structural integration of feudal forms into the logic of capital. Frank's critique, however, remained wedded to a level of abstraction which was unable to reveal the full implications of his suggestions. In this essay, I attempt to show that the logic of capital during colonial rule produced a municipal sanitation regime which relied upon the control over the labor of manual sweepers mediated through jobbers, overseers and contractors. Far from being the embodiment of "tradition", the sweepers since colonial India bear on their bodies the marks of capital. This essay reveals those marks as well as demonstrating the integral relation between the logic of capital and barbaric colonial rule.

Liberty, equality, fraternity, love, honor, patriotism and what have you. All this did not prevent us from making anti-racial speeches about dirty niggers, dirty Jews and dirty Arabs. High-minded people, liberal or just soft-hearted, protest that they were shocked by such inconsistency; but they were either mistaken or dishonest, for with us there is nothing more consistent than a racist humanism since the European has only been able to become a man through creating slaves and monsters (Jean-Paul Sartre, 1961). ${ }^{2}$

Contemporary social history of colonialism takes as its object of critique a colonial epistemology which sought to render the "East" as something immutable and, therefore, condemned to its own authoritarian logic. This colonial understanding of the "East" was constructed after a prolonged relationship with the peoples of Asia and after a series of bitter debates within the camp of colonialism. By the time the conquering Europeans began to erect a regime on the dustheap of the previous polities, they had adopted the viewpoint that the vanquished natives had no title to the

${ }^{1}$ Elisabeth B. Armstrong and Gyan Pandey read through the essay and gave me very thoughtful suggestions.

2 Jear-Paul Sartre, "Preface", in Franz Fanon, The Wretched of the Earth (New York, 1968), p. 26. 
benefits of modernity. The natives had to be controlled, they had to be monitored and they had to produce - their well-being was of no interest to the state. If they died, they could be replaced. When they died in large numbers, the colonialists feared more for their own health than for the loss of lives or the loss of potential workers. This Manicheanism, I have argued elsewhere, is the structuring principle of colonialism and of the construction of the colonial state. ${ }^{3}$

The very limited nature of reform in this colonial context meant that the liberalism which was introduced into the regime and the polity was itself utterly circumscribed. Ranajit Guha argues provocatively that the colonial regime in India ruled through "dominance without hegemony". 4 Order, Guha argues, is the idiom of state violence and that violence is allowed to intrude into all areas of life in India which it would not be allowed to enter in Britain. The regime had no compunction about violating its own standards of propriety because those over whom it ruled were not citizens, but subjects. Violence not only enters into every aspect of life in colonial society, but violence is itself immanent in colonialism. There is always the threat of violence, of coercion, of a few broken heads in a lathi (baton) charge. In 1806, Philip Francis declared to the House of Commons that "there was no power in India, but the power of the sword, and that was the British sword, and no other". Like a scepter, the sword hung over the heads of the natives reminding them of their subjection and warning them to be docile and obedient.

The violence of the colonial rule was made possible, however, by a series of complex maneuvers and not by a conspiracy or by a considered plan. The British found willing allies for their theory of Order in the authoritarian and feudal nobility. Once more the work of Ranajit Guha has illuminated the ways in which the British created alliances with dominant castes and classes to create the authority of the colonial state. The state shared the power of punishment, for example, with "the rural elite in the name of respect for indigenous tradition, which meant in effect turning a blind eye to the gentry dispensing criminal justice" who operated through their role as landlord or as village elder. The collusion between the colonial state and the rural elite "was indeed a part of the common experience of the poor and the subaltern at the local level nearly every-

3 Vijay Prashad, "Native Dirt/lmperial Ordure: The Cholera of 1832 and the Morbid Resolutions of Modernity", Journal of Historical Sociology, 7, 3 (1994).

"Ranajit Guha, "Dominance without Hegemony and its Historiography", in Subaliem Studies VI, (Delhi, 1989).

'Quoted in Ranajit Guha, A Rule of Property for Bengal (Calcutta, 1982; 1st ed. 1963), p. 146. 
where". ${ }^{6}$ The net result of this concentration of violence in the state and its allies was the revitalization of landlordism, which, in turn, reproduced the social relations of hierarchy and authoritarian practice.

Writing the history of labor in the jute industry of Bengal, Dipesh Chakrabarty argued that the Marxist category of "capital" is embedded in a particular "culture", a culture in which, Marx noted, "the notion of human equality has already acquired the fixity of a popular prejudice".? The "hegemonic bourgeois culture", Chakrabarty argues, "is an indispensable aspect of the social framework within which Marx locates his idea of working class consciousness". ${ }^{8}$ A study of workers in a colonial society where violence and dominance are main elements of its culture must be cautious of the categories which come from an altogether different historical milieu. As Chakrabarty points out, the "predominance of prebourgeois relationships seriously affected these workers in respect of their capacity to constitute themselves into a class by developing the necessary kinds of solidarity, organization, and consciousness". I want to underscore the importance of the constitution of authoritarianism in the very fabric of the modern colonial state. This essay takes issue with the belief that the imperfections of the colonial encounter are the imperfections of an already constituted "native tradition", a tradition which is both static and unproductive.

The main subjects of this essay are the street sweepers of Delhi. These workers in the sanitation department labored in a socio-economic formation in which extra-economic relations (such as authoritarian work practices) worked simultaneously with labor relations determined by the strictest logic of capital (contract labor). In the sanitation departments of the Delhi Municipal Committee (DMC) since the late nineteenth century, the burden of the city's sanitation fell on the sweepers. Far from rationalizing Delhi's sanitation system, the colonial regime fostered a system which relied upon extra-economic coercion which today gives credence to the lie that India is tradition enshrined: ${ }^{9}$ this essay argues that "tradition" is itself a child of colonial modernity, whose dynamic is neither progressive nor reactionary, but stagnant.

- Ranajit Guha, Elementary Aspects of Peasant Insurgency in Colonial India (Delhi, 1983), p. 7. This aspect of the critique of colonial knowledge, that the authoritarian structure was a "blending" of English and native feudal modes of power, was a major point of disagreement over Dipesh Chakrabarty's Rethinking Working-Class History, Bengal 18901940 (Delhi, 1989). A number of reviews in the journal, Economic and Political Weekly (28 July 1990 and 6 October 1990), invited a short response from Chakrabarty who reiterated the central point that the colonial situation blended British authoritarianism with native "undemocratic" traditions (27 April 1991).

7 Karl Marx, Capital I (Moscow, 1976), p. 60.

- Chakrabarty, Rethinking, p. 4.

" Jim Masselos, "Jobs and Jobbery: The Sweeper in Bombay under the Raj", Indian Economic and Social History Review, $19: 2$ (1981). 


\section{TYRANNICAL SWEEPERS}

In 1803, the British defeated the remnants of the Maratha army and took possession of Delhi, the erstwhile capital of the Mughal Empire. Between 1803 and 1857, the British held Delhi as a curiosity, allowing its administrators (such as the famous Charles Metcalfe) the luxury of exploration and of diplomacy. The British lived beside the Mughal sovereign, who continued his tentative rule over a curtailed Empire. When the peasants rebelled in 1857, the studied distance ended. The British terror in the aftermath of the revolt left Delhi with what one historian described as the "shadow of death". Poverty and demoralization, the historian argues, were the legacies of $1857-1858 .^{10}$ The British removed the Muslim masses from the city, exiled the Emperor to Burma, destroyed many of the buildings in the city, hung a number of rebels in the outskirts of the city and allowed swine to eat the soles of their feet. The British terror was memorable for its barbarism."

Anxious to consolidate legitimacy after its reign of terror, the British turned to lesser noblemen and to apolitical merchants for their support. While the regime was unwilling to share power, they were very willing to appoint loyalists onto a municipality. The Delhi Municipal Committee (DMC) was founded as a way to mediate the authority of the colonial state through established families who may not have enjoyed political power in the earlier regime. These loyalists were rewarded with wealth and with land, with titles and positions of honor. ${ }^{12}$ Both Muslim and Hindu merchants and petty noblemen found themselves under the watchful eye of the Chief and Deputy Commissioners who made most of the decisions in the city. The role of the natives on the Municipality was to mediate authority and to collect taxes; in return, they enjoyed the power to flaunt their close connection to the new sovereign. ${ }^{13}$ The task of the new administration was, as Veena Oldenburg succinctly put it, to keep the city loyal, to make the city pay and to keep the city clean. Cleanliness was as important in the tropics as loyalty. ${ }^{14}$

Tropical countries terrified colonial travelers and officials who believed that they harbored various malevolent diseases and miasmas. These dreaded and poisonous vapors, it was felt, invited death without warning. An early task of the newly established DMC was the collection of death rates and a medical survey of Delhi's environs, in order to find a suitable site for the British camp. Alarmed by the figures (61 per 1,000 in some areas), the British settled themselves in an enclave apart from the city.

${ }^{10}$ Narayani Gupta, Delhi Berween Two Empires, 1803-1931 (Delhi, 1981), p. 39. This book provides the most comprehensive urban history of the city.

"Brijkrishen Chandiwala, Dilli ki Khoj (Delhi, 1964), pp. 265-266.

12 Gupta, Delhi, p. 73.

13 C.A. Bayly, The Local Roots of Indian Politics, Allahabad, 1880-1920 (Oxford, 1975).

14 Veena Talwar Oldenburg. The Making of Colonial Lucknow (Delhi, 1989). 
The colonial regime's concern was restricted to the health of their troops, their bureaucrats and European civilians. Secluded in their colonial enclaves, the Europeans attempted to secure themselves from the biological warfare of native cities. ${ }^{15}$ The colonial regime appreciated the precariousness of their position, since the history of "Asiatic cholera" showed that distance did not protect them from its ravages. They needed to engineer their own enclaves as well as ensure that the sanitation of Delhi proceeded adequately (so as not to produce uncontrollable epidemics within the city walls).

The Europeans were not alone in their concern with disease and death. Delhi's nobility complained that after over six decades of de facto British rule "the arrangements for the cleanliness of the city are day by day less attended to". Far from being an inherent problem with their sanitation systems, the nobility argued, the problem lay in the unequal system which the British institutionalized. "Some parts of [the city] are well cleaned and lighted others are totally deprived of these benefits, which is highly unjust. As the octroi tax is collected from all the inhabitants alike, there is no reason why the benefits of the municipality should not be equally extended to all." 16 The native elite relentlessly criticized colonial rule for the inequities of urban services, since their taxes were syphoned off to beautify the colonial enclaves while largely neglecting the native city.

Yet, the municipal archive informs us that in this "Age of Improvement", it is the "traditional" sweepers who prevent Delhi from enjoying the just desserts of modern scientific and sociological developments. The brave municipal officer, we are told, "has been unceasing in his exertions for the improvement of the city; and his 'pluck' and untiring energy during the cholera epidemic elicited the hearty admiration of all classes." In order to produce an immaculate modernity, the colonial officials demonstrated a "most laudable zeal in this work of sanitary improvement". ${ }^{17}$ This was, to be sure, the dawn of local municipal bodies which concerned themselves with managing the Safety, Loyalty and Cleanliness of the city, tasks amply financed by House Tax, Octroi Duties and the largess of the colonial state's coffers. The historian of local selfgovernment in India points out that this was to prove to be a false dawn, since the municipalities did not devolve power to local residents nor were they terribly effective in producing the facilities of a modern city. ${ }^{18}$ Why did the municipality not produce a "neo-European city", an

is David Amold, Colonizing the Body. State Medicine and Epidemic Disease in NineteenthCenfury India (Los Angeles, 1993), ch. 2.

${ }^{16}$ Urdu Akhbar, 8 July 1871.

17 National Archives of India [NAI], Home (Sanitary), A Proceedings [Progs.], 7 November 1868, nos 5-6.

18 Hugh Tinker, The Foundation of Local Self-Government in India, Pakistan and Burma (London, 1954), p. 42. 
emblem of modernity? Was it because the sweepers chronically struck work and made it inconvenient for the municipality to do its work properly ${ }^{19}$ Or was it because the colonial regime followed the Manichean logic that development for the natives was premature and so their threshold for suffering and pain is greater - with cultural civilization comes the pleasure of technological pleasure and not vice versa. ${ }^{20}$

Frustrated in their ongoing battle with the colonial regime, the native elite joined with colonial officialdom to condemn the sweepers. Unable to specify the problem for the dirt in the cities, both elites fostered the illusion that it was the "traditional" sweepers who stubbornly fettered modernity. A rousing editorial in a local paper puts the problem squarely:

The haughty and overbearing behavior of sweepers is another nuisance. In all cities, they have divided mohallas among them, so that each is the sole and hereditary lord of his circle, and troubles poor persons by refusing to remove filth from their houses, and in many cases leaving them uncleaned for several days till his demands are satisfied. The people, knowing that they cannot change their sweepers, and fearing lest they should make false and calumnious reports against them to the police, and thereby involve them in troubles, tamely submit to their oppression. This conduct of sweepers is the cause of the houses of the people constantly remaining in a dirty state. ${ }^{21}$

The sweepers held the city to ransom; if the city did not honor their often meager demands, they refused to carry the garbage outside the city. Since the sweepers worked together, controlling their own mohallas [neighborhoods], the householders could not hire outside sweepers to remove their trash without incurring the wrath of the mohalla sweeper. The mohalla sweeper held an alienable right on the removal of refuse in his or her mohalla, a right which could be transferred by sale or mortgage. There is evidence of mohalla sweepers hiring other people to do their work, but this does not seem to be the rule. ${ }^{2}$ Householders paid their sweepers in daily dues given in food, monthly dues in cash, dues on certain domestic ritual occasions such as marriages and deaths, and dues on certain annual festivals. The sweepers also controlled the manure, that waste-as-ore which was exchanged with the farmers for cash or kind.

The sweepers worked hard for their remuneration, and when these wages did not come or if the householders treated them with disrespect, they refused to remove the refuse. The sweepers formed a community which acted in concert to protect their combined interest, i.e. their control over the waste-as-ore as well as their self-respect as sweepers, as a community of Mehtars. They did control the waste, and they fought

\footnotetext{
19 William Crooke, Natives of Northern India (London, 1907), p. 122.

${ }^{20}$ Prashad, "Native Dirt", section IV.

21 Urdu Akhbar, 1 December 1871.

22 NAI, Home (Public), A Progs., 4 February 1859, nos 68-71.
} 
for that control only because this was their means of survival. Without control over and possession of their means of survival the sweepers had nothing, least of all their reputations. ${ }^{23}$

The sweepers' control over their means of survival was described by colonial officials and the local elites as the working class ganging up on the thinking class. "If any housekeeper within a particular circle happens to offend the sweeper of that range," Sleeman wrote in 1844, "none of his filth will be removed till he pacifies him, because no other sweeper would dare touch it; and the people of the town are more often tyrannized by these people than by any other." ${ }^{24}$ This statement is symptomatic of an emerging modern sentiment towards the working class, one which seeks to over-exaggerate the power of the sweepers in order to make them look ridiculous. The sweepers tyrannize the populace, and yet it is only if some action or look (accidental, perhaps) "offends" the modesty and sensitivity of the sweepers that they (as tyrants) show their force. That the sweepers must put up with the force of social persecution from both the local elites and the colonial rulers is not noted. The guilds were not, as is obvious, in the elites' interests. The elites expressed their discomfort with the guilds by asking the DMC to allow them to "change sweepers whenever they liked". This would strip the sweepers of control over their means of survival, which would be "entrusted" to the colonial state and used at their behest. The problem of keeping the city clean was of a bigger magnitude than simply the "wicked behavior of the sweepers [which left] the houses of the people in a filthy state, in consequence of which children contract diseases and die in numbers". ${ }^{25}$ For the elite, the immediate association of the sweepers with the collapse of municipal services had more to do with the fact that the sweepers once controlled the refuse removal system. Now with the expansion of the city's scale, with the diversion of the city's resources to the colonial enclave and with the structural decay of the city infrastructure, it was easier to ask the colonial rulers to discipline the sweepers, for in these days of misfortune the sweepers ruled the masters.

The elite's fear of being reported to the police was not a conceit, for it was a real threat. From the early nineteenth century, the British Resident paid the sweepers to collect intelligence from all the quarters of the city. The sweepers had access to every alleyway each day, which meant that they were able to detect extraordinary developments and to listen to the bazaar gup [rumor]. The sweepers considered themselves

23 Hazari, Untouchable. The Autobiography of an Indian Outcaste (New York, 1969; 1st ed. 1951), pp. 8-9. The phrase "means of survival" was suggested by Gyan Pandey.

24 Major General Sir W.H. Sleeman, Rambles and Recollections of an Indian Official, ed. V.A. Smith (Karachi, 1973 (1844/1915)), pp. 49-50.

2s Urdu Akhbar, 1 December 1871. For a discussion of the bigger magnitude, see Vijay Prashad, "Modern Involution - Waste Technology and its Limits", Revolting Labor: The Making of the Balmiki Community (Ph.D., University of Chicago, 1994). 
"confidential officers of the Government, and may in general be depended on as such". Not only did the sweepers act as the conduits of intelligence for the police, but they also collected vital statistics for the DMC. ${ }^{26}$ The collection of information, whether for police intelligence or to fill the mortality lists, sowed seeds of suspicion in the minds of the city residents. In the eyes of the elites, the sweepers were agents of the colonial regime, but in the eyes of colonial officialdom the sweepers were an undisciplined gang who did not work effectively and often went on strike. For different reasons, both the colonial and native elites distrusted the sweepers.

\section{FREED FROM THE MEANS OF PRODUCTION}

Without a doubt, the sweepers did control their own labor process as they came to clean at their own time and at their own speed. Dirt left the boundary wall of homes only to enter the public space of the street, to remain there to putrefy. The task of the sweeper was to remove the accumulated dirt and dispose of it, in order to remind the residents of their civility and to hide the city's own refuse from itself. The sweepers came late, however, late enough for colonial officials to see the garbage and to smell it putrefying. "Many of the lanes looked as if they had not been swept for several days," a colonial official reported, "heaps of rubbish were lying here and there, and I saw several heaps of street sweepings and matter from private houses lying in the smaller streets as late as 10 o'clock."27 The sweeper needed to be brought to task, a phrase which implied that their independence, their control over their labor, the waste-as-ore and above all, their own parochial notions of time needed to be curtailed.

On 4 September 1882, the DMC decided that "early action must be taken in view of securing the entire nightsoil of the city with the double object of securing the better sanitation of the city and insuring the sale of the filth collected at the Depots". The authorities were sure to point out that "until the interference of the private sweepers is effectually stopped, neither the sanitation of the city nor the sale of the filth can be ensured". ${ }^{28}$ Sweepers sold the nightsoil to hinterland agriculturalists for a reasonable sum in order to increase their earnings incrementally. The sweepers collected their meager wages from neighborhood residents and from the municipality. To supplement their wages, the sweepers

26 Charles Metcalfe quoted in T.G.P. Spear, Twilight of the Mughals: Studies in Late Mughal Delhi (Cambridge, 1951), p. 92. On the gathering of vital statistics, see Delhi Municipal Corporation [DMC] Progs., 27 June 1887, 16 January 1888, 3 July 1893 and 6 November 1893.

77 DMC Progs., 19 September 1887.

20 DMC Progs., 4 September 1882. 
went through the refuse to recycle anything of value, since for them garbage was the ore out of which they extracted or fashioned value. The DMC understood this and they used this knowledge to justify their policy of controlling the "ore" on two counts: to deprive the sweepers of an independent existence (i.e. wages from the householders and earnings from sale of ore rather than a "full" municipal wage) and to enable the DMC to profit on the sale of the nightsoil as manure. In 1873 and 1876, the sweepers went on strike to fend off the DMC's challenge. The sweepers won these early battles and the "officials had to admit defeat and allow the sweepers to retain their monopoly and did not enroll them as paid servants of the Municipality". ${ }^{29}$ In 1879, the sweepers threatened to strike once more, "to be followed by legal proceedings if their monopoly over nightsoil was interfered with or their birth rights disturbed". The history of the Delhi Municipality tells us that "these rights had all along been a very great stumbling block to the improvement of the mohalla", but it does not tell us that these "birth-rights" were also a stumbling block to the municipality's policy to control the sweepers' labor. By the early 1880s, however, the official history tells us that the "Committee gradually got more and more control over the sweepers of the city". ${ }^{30}$

The DMC marshaled its forces. First, it built up their hardware: carts to remove refuse and a warehouse to store the nightsoil. Then, in 1882, they took action. ${ }^{31}$ In response, seventeen sweepers submitted a petition which promised a strike "in consequence of being deprived of the city's nightsoil". ${ }^{32}$ A year later, the DMC responded to the already despondent sweepers' petition, and the curt response challenged the sweepers to stand up to the might of the Empire. ${ }^{33}$ In 1884 , the DMC passed a resolution to "enforce their right to the monopoly of all the nightsoil and sweepings of the city proper". ${ }^{34}$ They invoked a "right" superior to the "customary right" of ownership and control exercised by the sweeper; this was the right of conquest as well as a right exercised in order to create a more efficient system. The canons of custom were being rewritten by the colonial officers; what remained was to use the cannons of the law to uphold these strictures. The law spoke soon after in that unmistakable tone of the colonial state's emissary: "on and after 1st December 1884 the removal of nightsoil from the city, except by the servants of the Committee be strictly prohibited". ${ }^{35}$ By 1885, the

29 Gupta, Delhi, p. 161.

${ }^{30}$ Rai Sahib Madho Pershad, The History of the Delhi Mtunicipality, 1863-1921 (Allahabad, 1921), pp. $47-48$ and p. 59.

${ }^{31}$ DMC Progs., 20 October 1882.

32 DMC Progs., 6 November 1882.

${ }^{33}$ DMC Progs., 7 August 1883.

34 DMC Progs., 12 February 1884; DMC Progs., 4 September 1884.

3s DMC Progs., 2 December 1884. 
nightsoil of the suburban wards of the city was also secured by the DMC. ${ }^{36}$

Delhi's sweepers did not surrender their history of struggle, written in a language of autonomy and independence, upon hearing Town Hall's pompous declaration. Refuse was not surrendered to the authorities, and the DMC called attention to "the matter of the surreptitious removal of the nightsoil". The officials asked their subordinate officers to "exercise greater vigilance and control in preventing removal of such other than by Municipal Staff". ${ }^{37}$ In 1886, Mohammad Ikramullah considered the Municipality's options with regard to the surreptitious removal of nightsoil and he found the legal ramifications unclear. ${ }^{38}$ One of the easiest ways to monitor the removal of nightsoil was to have dalaos [depots] on each street and to have the mohalla sweepers bring the nightsoil to these sites under the vigilant gaze of the overseer. ${ }^{39}$ The dalaos played an important role in the struggle to control the movement of nightsoil, so much so that the DMC passed a resolution to "prevent mohalla sweepers placing filth anywhere else, or even if placed at the fixed dalaos to compel the sweepers to place the filth inside the receptacles and not outside them". ${ }^{40}$ Once the nightsoil was collected inside the dalaos, the sweepers moved on to the next worksite; other sweepers, with their "filth carts" removed the refuse outside the city.

Since the DMC systematized the flow of refuse outside the city and since they kept a steady eye on the sweepers at all times, surreptitious removal of refuse became increasingly difficult. Nevertheless, well into the twentieth century, the municipal archive bristles with stories of pilfering and theft, but direct sales to farmers became the general practice.

\section{“FREED" INTO WAGE-LABOR}

Independence is not just about an attitude, a frame of mind, but it is also about being able to materially take care of oneself and of one's community. Delhi's Mehtars were independent by having control over the waste-as-ore to sell to the farmers and to recycle and repair broken items; here we might equate them with the "pockets of peasants" whose cries still echo in the streets of Delhi to collect and sell the accumulated kabari. $^{41}$ Their independence came in their collective bargaining for wages from the householders, a bargaining power drawn from a low

36 DMC Progs., 1 June 1885.

${ }^{3}$ DMC Progs., 5 April 1886.

3s DMC Progs., 9 August 1886.

37 DMC Progs., 5 March 1887; DMC Progs., 2 July 1888.

40 DMC Progs., 4 September 1889; Section 127 of Act XIII (1884) was available to the DMC to use against the sweepers on this issue.

"Vallabhaswami, Safai: Vigyan aur Kala (Varanasi, 1957), p. 3. 
caste monopoly on what high castes considered to be a demeaning practice. The sweepers, we hear in the early nineteenth century, "cannot be readily coerced because no Hindu or Musalman would do their work to save his life, nor will he pollute himself even by beating the refractory scavenger". ${ }^{42}$ Without romanticizing the sweepers' labor, I want to underscore the control the Mehtars had over their working lives, a certain freedom which came from their control over the inflow of resources into the community and from their ability to stand apart from the behest of patrons. The municipal authorities begrudged the sweepers their independence, since it threatened the authority of the DMC; what was needed, in their eyes, was a mechanism to tie the sweepers to the DMC. That device was the fixed municipal wage.

From being a part of the neighborhood (without living in it), the Mehtar became a municipal employee with no direct link with the families in the homes along their routes. The municipality delegated sweepers to neighborhoods, thereby disrupting the relations of clientship and servitude cultivated through the sweepers' negotiation with certain families for their sources of sustenance. The pre-colonial relations were not without social contradictions and structural violence. The politics of the city was rent with fissures before the British took charge of the city. ${ }^{43}$ With the British entry, the sweepers adapted from one form of politics to another. We are not in the business of valorizing one past over another; the point is to demonstrate how the social form of the colonial regime was forged and the nature of its impact upon the sweepers of Delhi.

At one level, the sweepers in the colonial setting were indeed free from the servile bonds which trapped them into relationships with exploitative upper castes. At another level, however, the sweepers were freed from their ownership and control over the processes of their work they did not control the relationships in the mohallas as they used to, since now they could not directly bargain with the householders by boycotting work. Redress for the sweepers could only come from the municipality. The state, through the municipality, mediates between a conflict which pits sweeper against householder: the colonial state, we might say, absorbs the conflicts in the interests of "efficiency" and "order" (or, in the interests of keeping the status quo in favor of the alliance between the colonial and native elites). Mediation, here, is conducted through the instrument of the wage.

Once the municipality centralized the source of sustenance, they effectively controlled the sweepers. The wage relationship reduced the space for bargaining which the sweeper experienced in the mohalla, a bargaining which produced a measure of cruel negotiation. The sweepers

Sleeman, Rambles, Pp. 49-50ff.

'Syed Abdul Gafoor Shahbaz, Zindagania Benazir (Delhi, n.d.). 
did not want to succumb to the wage easily because they knew that it entailed being mere employees of the DMC. The new forms of labor were, therefore, purchased through the law. The Town Hall sent forth bold pronouncements which declared that because "the sweepers are permanently employed and in receipt of full wages, the Committee declines to permit them to take private work of any kind". " From 1881 to 1885 , mohalla sweepers received Re. 1 per mensem from the DMC, a sum which they supplemented with neighborhood emoluments and sale of refuse. In 1885, however, the DMC hired them as "permanent sweepers" with the total wage of Rs. 4 per mensem, a figure even the colonial bureaucrats agreed was far lower than the total earnings of the sweeper under the old system.

The DMC shifted other costs onto the sweepers as well. Out of the annual salary of Rs. 48, the sweepers defrayed half the cost of their winter uniforms, a cost which they did not have to bear earlier since they did not wear uniforms. The municipality insisted upon the wearing of the uniforms for the sake of labor discipline, but also for the sweepers to be known by "some distinguishing mark", mostly to facilitate monitoring rather than to inculcate pride. Monitoring was a major interest of the colonial authorities who insisted that the sweepers be registered annually at the Town Hall. ${ }^{45}$

The sweepers, the Town Hall says, are "permanently employed and in receipt of full wages", for which reason they cannot take "private work" or cannot make "private" arrangements with householders. The phrase "full wages" was a notable one, for it implied that the sweepers received all that their labor power was worth, no more and no less. It was not a "fair wage", but a "full wage", the fullness of which was conjured up by a mathematical wizard. With the sweepers' salary fixed at Rs. 4 per mensem, it is no surprise that the rise in prices of essential commodities in Delhi from the early 1870 s encouraged Mehtars to demand more than this "full wage" (the grain riots of 1877 is one early indication of militant unrest among the working classes in response to rising prices during the decade of the 1870s). Evidence from the famine of 1898 shows that mainly low castes frequented the public works. The description of these castes as "a most miserable looking lot, many diseased and wretchedly poor", gathering under the benevolence of the Baptist Mission and Lala Jugal Kishore to eat at a free kitchen shows the wretchedness of their situation. Mehtars, even with a fixed wage, could not support themselves through a period of rising prices, for their fixed wage was not adequate for secular prices let alone famine prices. ${ }^{46}$

"DMC Progs., 4 May 1885.

15 DMC Progs., 1 June 1885; DMC Progs., 4 January 1886; DMC Progs., 1 October 1888; DMC Progs., 4 August 1890.

* Michelle McAlpin's article in Dharma Kumar (ed.), The Cambridge Economic History of India (Delhi, 1984); NAI, Home (Police), B Progs., October 1877, nos 18-19; NAI, Home (Police), B Progs., December 1877, no. 9. 
Aware of the lack of positive response from the sweepers, the DMC warned them in strong language that they must not challenge the onslaught of modernity:

If any Mohalla sweeper who by custom or hereditary right receives fees from the residents of that Mohalla willfully or negligently omits to clean the private privies or premises of any such resident or willfully or negligently omits to remove any nuisance in that Mohalla which it is his duty to remove he shall be punishable with fines which may extend to ten rupees and with a further fine which may extend to one rupee for every day after the first during which the offense is continued. ${ }^{47}$

The DMC fixed a steep fine on the sweepers' salaries for rebellious behavior. A fine of Rs. 10 was more than a threat, and it must have driven the fear of the moneylender and the jail into the hearts of the sweepers. There can be no stronger indication of the colonial anxiety over sweepers' strikes than the unreasonableness of the Rs. 10 fine, allowing the workers no room to bargain for higher wages. In November 1888 , the DMC halved the Rs. 4 salary, an act which the sweepers considered so unreasonable that they risked a strike. ${ }^{48}$ Few disincentives matched up to the most glaring incentive for a strike: a criminal wage cut.

The strike of 1889 was the final defeat of the sweepers at the hands of colonial officialdom. After this, the sweepers began to internalize their role as municipal employees and "forget" their history of independent control over their laboring lives. The strike was lost for the most part because the sweepers did not enjoy the vital support of native elites whose support in the 1870 s was crucial. The earlier backing came in most part as a holdover from the elite's memories of colonial brutality in 1857 and distrust of the foreign invader; by the 1880 s, this elite rebelliousness withered, to be substituted by a constitutional nationalism from among the emerging middle class (industrialists, merchants, bankers, traders) and some old princes. In fact, in the 1880 s the native elite pressured the municipality to take some action against the sweepers and to make them servants of the burghers, and not lords of the streets. The interests of the local elites and the colonial bureaucracy coalesced on the issue of controlling menial labor. The sweepers took action, we are told, because they believed that the DMC did not have a by-law under which they could be punished; this was indeed so, but it changed soon enough as the DMC took pains to fabricate necessary legal powers to squash the audacious sweepers. On 1 February 1892, the secretary of the DMC banged his gavel on the meeting table at the Town Hall to end the twenty-year struggle. Under section 118 of Act XX of 1891,

4 DMC Progs., 2 July 1888; the fine of Rs. 10 was adjudged to be high enough to remain till the next century, see section 165 on p. 157 of the Punjab Mfunicipal Act, 1911, Chandigarh, Punjab Law Agency, 1988.

48 DMC Progs., 6 November 1888. 
the municipality could prosecute mohalla sweepers who neglected their statutory duties. The municipality's punitive action was to "prove to the public the fact that customary sweepers can now be prosecuted for not doing their work properly".49

\section{COLONIAL CULTURE, COLONIAL CAPITAL}

The DMC did not want the sweepers to control themselves, since they considered such a policy inefficient in terms of ordure and dangerous in terms of order. The municipality preferred to run the sanitation department under direct management. Now with the fines and other legal weapons driving the fear of indebtedness into the hearts of the sweepers, the municipality put their trust in the gradual normalization of discipline among the subordinate staff. Realizing, perhaps, that the norms of discipline are better internalized where bourgeois value attained the fixity of a popular prejudice, the colonial bureaucracy sought out a "responsible person" to monitor the sweepers and to be "held liable in the event of ordinary rules of conservancy being neglected"..$^{30}$ This "responsible person" was to enforce the legal dicta and goad the sweepers to do their tasks efficiently. However, such a system would put an inordinate amount of stress on the monetary and manpower resources of the DMC. To run the sanitation department "on the cheap", for such is the fate of modern municipalities and especially colonial municipalities, the colonial bureaucracy came up with two solutions, both of which are used to the present day: the contract labor system and direct management maintained cheaply with the active assistance of the Jamadar (the jobber and overseer). The DMC used both modes of managing labor simultaneously, with one mode often utilized to keep the other in order. When the colonial officials felt that the legal contractors tried to establish an oligopoly, they enhanced their parallel system using the Jamadars to gather labor and their stored carts to remove refuse.

\section{CONTRACT LABOR}

In 1887 we get our first indication that the removal of refuse is to be given out on contract. ${ }^{51}$ The DMC divided the city and its suburbs into twelve wards (12 in 1871 and 15 by 1884) and offered tenders to contractors for each ward. Contractors bid for as many wards as they wished, as long as they demonstrated their ability to manage the work.

DMC Progs., 1 February 1892.

so NAI, Home (Sanitary), A Progs., October 1887, nos 125-135; DMC Progs., 4 July 1887.

s1 DMC Progs., 31 March 1887; DMC Progs., 1 March 1888; DMC Progs., 5 March 1888; DMC Progs., 2 April 1888. 
At public auctions, the contractors bid for the tenders as the DMC tried to draw their fee down while trying to find a "responsible person" to operate the tender. Until 1912, there was no major conflict between the municipality and the contractors. While the municipal archive contains a number of civil suits made against the contractors for not fulfilling their contracts, the municipality seemed to indicate that this was part of business as usual. No major investigation was carried out on the contract system, only reports of minor infringements such as charges of slack work.

In 1912 all this clanged. The stakes of the sanitation of the walled city rose due to the presence of the new Imperial capital. It is important to bear in mind the words of the Viceroy's assistant written to the Sanitary Department, words which illustrate the new importance of Delhi after its century of neglect: "It does not seem to me that the sanitary policy of Delhi is on the right scale, or that it is realized that our object is not to clean up the filthiest place which I have seen in India, but to make old and new Delhi sanitary on the modern European scale. If any part of your work must be sacrificed it must not be Delhi."52 To run a sanitary operation on a "European scale" necessitated an expansion in the financial resources of the municipality. Since this was not forthcoming, one of the remaining options was to enhance the establishment, to make the organization operationally efficient.

The sanitation department was run by a Health Officer who was assisted by a number of subordinate managers (these included at the lower end the Jamadar); these managers monitored the activities of the contractors to see that they did not violate the terms of their contracts. As far as the municipality was concerned the fact that the contractors "ran" the cleaning operations put the entire system at risk: these natives, albeit men of business, could not do their work properly and with no external competition to give them incentive they ceased to progress. The DMC felt that if they ran some sections of the city using their own plant and establishment, they would be able to control the contractors as well as pre-empt the formation of an oligopoly. If the contractors refused to do something, or if they went on strike, the municipality would make it known that it was quite capable of running the operations itself. In 1912, therefore, the DMC took charge of six wards (1 to 5 and 12), using their own bullocks and carts. It needs to be noted that wards 1 to 5 lay at the north of the walled city and ward 12 was Subzimandi, each of these areas adjacent to the Civil Lines, at that time still the European enclave of the city. In 1915, the DMC increased the staff of its bullocks department and contemplated taking over the remaining wards. The contractors, in retaliation, went on strike to protest

32 NAI, Education (Sanitary), A Progs., March 1913, nos 73-75; Harcourt Butler to Major Robertson, 20 December 1912. 
the harsh terms of the DMC, since these developments augured their extinction. The DMC fired them all and in 1916 severely punished the new contractors of wards 9 and 10 for "these contractors did their work miserably and took very little trouble in removing filth from the dalaos and refuse from the dust bins of their wards". The DMC dismissed them and confiscated their securities. ${ }^{53}$

Who were these contractors and did they merit this sort of mistrust? The municipal archive tells us that they cannot be trusted because they come from the "sweeper class", which is meant to make us despair yet again for the "pluck" of the colonial officials, as they have yet again to bear with the inefficiencies and sloth of the sweepers. The fines did not produce discipline since the contractors "never carry out the terms of the contract" and the DMC is put through "continued anxiety". ${ }^{34}$ They cannot be disciplined, because just as in their incarnation as sweepers who conducted boycotts, here too they band together and prevent the work from getting done. "As the customary house sweepers are related to one another", the Health Officer wrote in February 1935, "the sweepers owning bullocks are not ready to do the work left over by their kinsmen." It would be a mistake to believe that the contractors were "customary sweepers" or that the sweepers as a corporate group controlled their own labor; there is no evidence to show this. What evidence there is shows that some "sweepers" bid for tenders and, as "contractors" they controlled a number of wards. Not only do a few contractors control all the wards, but at the auctions for the contracts "cliques are formed" by a group of contractors to bid for all the wards." These contractors are "rich sweepers", and this is the charm of the system: it is able to take part of an organic community which has come out of a period of struggle and pit this part against their brethren. A community-in-formation is disrupted here by "individual" advancement at the cost of the rest of the community, a theme which was later to attract attention as the formation of an elite among the untouchables. A community-in-formation is broken up by a structuring practice which prefers to pit people against each other in order to cut costs.

The perfect example of a "rich sweeper" offering low tenders is the infamous Bulaki who bid for so many contracts at such a low rate that he went bankrupt trying to fulfill them. The DMC happily accepted his tendered bids for their cheapness, even though they knew that such bids could not be fulfilled in an efficient manner. Consider a contractor who offered to remove the refuse from a part of a ward in 1933 for Rs. 110

s3 K.S. Sethna, Report on the Administration of Delhi Mfunicipality, 1916-1917, vol. II (Delhi, 1917), pp. 32-33.

34 For this discussion I am using Sethna, Report; DSA, CC (Education), B Progs., 6(7), 1927; DSA, CC (Education), B Progs., 4(11), 1929; DMC Progs., 1929; DSA, CC (Education), B Progs., 4(6) 1935; DMC Progs., 1935.

ss DMC Progs., Sanitation Sub.Committee, 16 August 1929. 
per mensem. ${ }^{56}$ He turned over Rs. 10 of this to the local Jamadar, "the remover of all obstacles", who as petty supervisor turns a blind eye to the overloading of carts and the unhygienic dumping of refuse in watercourses and in hollows. To remove the refuse the contractor used six refuse carts, given by the DMC, but he could only afford to keep three or four bullocks, with each bullock forced to run about two or three trips a day. The cost for the bullocks was Rs. 45. The contractor hired two carters to whom he paid Rs. 30 per month to run two trips daily. If a carter fell ill or if a bullock went lame, the contractor hired carters or bullocks at a daily rate of about Re. 1. The DMC contract attained the status of a commodity which some contractors sold to sub-contractors for a commission; needless to say, the colonial officials did not take this kindly given their desire to centralize power. Leaving some petty cash for such wages of sweepers hired to load the cart, other miscellaneous expenses and other bribes, the contractor earned Rs. 20 per mensem. If he wished to make a larger profit he cut corners in imaginative ways such as in the overloading of carts taken per trip and in the feed for the bullocks. Many of the carters' and sweepers' wives worked as domestic servants within the mohallas and had access to jhuta [left-over] food which they collected and fed to the bullocks. The municipal record gives us access to some of the other short-cuts which the contractors resorted to, as they were censured for their "negligence". The Sanitary Inspector, for example, caught the sweepers of Jawahar as they dumped the refuse from their ward area into the drain; the refuse blocked the drain and it burst. Jawahar lost his contract. ${ }^{57}$ For the last half of 1934, the DMC collected Rs. 529 per contractor in fines. By 1935, seven of the contractors were "in debt, with their salaries attached in court". Some contractors had their contracts transferred and they left this line of work..$^{58}$ In turn the contractors shifted part of the burden of debt and fines onto the laborers, whose meager wages already suffered the weight of price inflation.

The workers, without doubt, paid for the cost of such an enterprise with their low wages, bereft of benefits. Such so-called external economies or diseconomies are defrayed by the municipality onto the contractor, who in turn shifts these costs onto the labor force. For the contractor to earn a moderate (if not larger) profit while honoring their low tenders (without developing existing technologies), they can only adjust their recurring costs. The worker suffers, but so does the physical plant (such as carts) and the ecological system (dumping the untreated waste into drains and into the river). These diseconomies show how the

s6 This example and much that I say on the subject is from N.R. Malkani, "Sanitation of an Imperial City", Harijan, 30 September 1933.

57 DMC Progs., Sanitation Sub-Committee, 12 July 1929.

ss DMC Progs., Sanitation Sub-Committee, 27 February 1935. 
legal contractors were indeed able to "honor" their low tenders, make a profit and remain working with an undertechnologized process for refuse removal.

For the sweepers, the contractor embodied the brutality of the system. It was not the British officials, the Chief and Deputy Commissioner, who came on the rounds, but it was the contractor. Under pressure to. keep costs down, the contractors used all sorts of means including physical violence and threats. There are a few cases of overt resistance, of retribution extracted by some sweepers against the contractor. Since the relations of the contractor and the sweepers are outside the proper realm of the state, the official bureaucrats did not pay that relationship much heed. In some cases, they had to keep a record of the incidents. For example, in 1929, the sweepers of Sami Ahmed gathered at his house and threatened to kill him and the moneylender Kallu Mal Bania. Their wanton ways with money angered the sweepers' sense of justice. ${ }^{59}$ In the main, the sweepers had very few opportunities to confront their contractors, whose relations with the police were certainly close. Comfortable in the belief that the culture of colonialism was simply the culture of the "indigenous tradition", the colonial regime did not seek to defend the sweeper. Rather, they championed the system.

"The Delhi Municipality", Malkani wrote in 1933, "has found the contract system the cheapest, for bidders bid the lowest and make it up by bribing Jamadars and using Jhuta. The bullocks are well fed and can do 12 hours work per day; the Jamadar's palms are well greased, he does not mind how many carts carry or don't carry the refuse of the city." Nevertheless, the DMC found that the contractors remained "indifferent and negligent in their work" and anaesthetized to fines and reprimands. "These contractors", we are told, "were under better control when the Municipal Bullock Department was in existence", i.e. prior to 1930. The Bullock Department, however, did not outlast the weight of corruption; for example, the grain intended for the animals was sold in the open market, the oil for the animals was used to "fry pakories for Jamadars", as a consequence of which "the bullocks were always ailing". "In haste", our informant tells us, "the bullock department was closed and the contract system fully adopted - to save public money!" Yet, the municipal authorities held that the "principle of the lowest bidder" must stand, although they accepted that this itself "resulted in the neglect of the work". In 1935 an official suggested that the DMC abolish the contract system and take charge of the conservancy system themselves, but the suggestion was declared out of order. ${ }^{6 t}$ For

59 DMC Progs., Executive \& Finance Sub-Committee, 4 February 1929.

Malkani, "Sanitation".

61 DMC Progs., Sanitation Sub-Committee, 27 September 1935; DMC Progs., Sanitation Sub-Committee, 6 February 1935. 
the DMC, the contract system provided a way for them to be efficient: with a minimum of effort (input) on their part, they were able to enforce reasonable cleanliness (output). In commercial terms too, the contract system was efficient: for a minimum of money inputs (recurring costs), it was able to remove the city's refuse. Having defined their problems with the system as problems with individual contractors (who could be replaced), the DMC was unable to see the flaws in the system itself. What was not recognized (and this is why the system continued) was that the actual costs which the city expended on the system far outstripped the apparent functional and commercial efficiency of the contractors. Given chronic health problems due to dumping in watercourses and broadcasting intestinal parasites into the air, the low wages to the workers who then needed to lean on their links with their families to enable them to survive (no accumulation of capital among this underclass), the corruption which began to develop as contractors formed an oligopoly with the connivance of the DMC, how was it possible to use the word "efficient" to describe this system?

\section{JAMADARS}

In 1912, when the colonial bureaucracy wanted to invest Delhi with a sanitary system on a "European scale", one of the things they had in mind was a European health officer. A "missionary of sanitation" was needed, someone with the sort of "technical knowledge" which a "bazaar sergeant" does not have. The man who supervised the conservancy operations in Delhi until 1912 was a "worthy and kindly gentleman, who is liked by the people", but he "does not carry sufficient weight to make himself felt or to insist on the carrying out of his recommendations or orders". In other words, an amateur could not do the work of a technocrat, and so what was needed was a European Officer of the Indian Medical Service.62 In July 1912, Major A.W.C. Young was seconded to Delhi as the Health Officer. Without a moment's delay, he declared that the reorganization of Delhi's sanitary services could not take place until the "trammels of petty local considerations and parochial ideas are cast aside and there is whole-hearted concentration on program and efficiency". The Viceroy, Hardinge, himself found that Delhi's sanitary system was "prehistoric" and needed to be overhauled, such support for a local program being unprecedented. ${ }^{63}$ One of these "prehistoric" barriers in whose person was congealed the petty local considera-

62 NAI, Education (Sanitary), A Progs., September 1912, nos 9-19, Resolution drafted by District Commissioner H.C. Beadon; NAI, Education (Sanitary), A Progs., January 1912, nos 50-65.

63 NAI, Education (Municipalities), A Progs., April 1914, nos 18-19; NAI, Education (Sanitary), A Progs., September 1912, nos 9-19, letters from R.H. Craddock (5 June 1912) and Viceroy (7 June 1912). 
tions and parochial ideas was the Jamadar, the jobber and overseer (variously called Conservancy Daroga, Safai Daroga, Muqaddam, Sardar, et al.). Without this prehistoric barrier, however, the entire system could not function cheaply and efficiently. Since the municipality did not want to divulge all wards to the contractors, it retained some to run itself. The everyday running of these wards was in the hands of the Jamadar. The role of the Jamadars was an important one, since they served as a way for the municipality to confine the power of the contractors as well as to manage the service for the least cost.

The Jamadar, colonial records indicate, was a "well-meaning person, but he has received no training, his pay is only Rs. 20 per month and his understanding of his duties is little greater than that of the mehtarani who early that morning made her rare offering of fine, sharp sand at the public latrine". This sort of stereotype grossly underestimates the shrewdness of the Jamadar who used his privileged position to draw a steady surplus from the workers. He (all Jamadars appear to have been men, unlike the case in the textile industry in Bombay ${ }^{64}$ ) manifested his power in physical strength, spending many hours at the akharas [gymnasiums] to demonstrate his physical power. He roamed among the homes of the sweepers, to make sure that nothing went by without his knowledge, as well as to show that he had access to all the sweepers' private spaces. The Jamadar was a well-known character in contemporary fiction, and Premchand's Jurmana (1931) offers us a window into his legendary extra-economic coercion. Allarakhi worked hard as a street sweeper, but that was not enough for her Jamadar who harassed her with his threatening sexual advances. His threats led to a fine on her six-rupee salary, as she was left with the lingering feeling that she might be fired at any moment. ${ }^{65}$ The Jamadar, in other words, appeared to the workers as their overlord, just as at times he might be their protector. The structural position of the Jamadars, in the middle between capital and labor, already put them in a position of power. When they discharged the DMC's orders, for example, they enhanced the orders to fit in with their own immediate interests. If a favorable message was to be transmitted, it was done in their own name ("I struggled to get you this benefit"); if an unfavorable order was given, it was done in the name of the municipality ("I tried to prevent it, but on this they would not budge"), but in all cases it was done with the intent to aggrandize the Jamadar himself. Proximity to power endows power in itself.

Jamadars in the Bombay textile industry came from among the rank and file. They enabled the mills to secure a steady flow of labor from

44 Dick Kooiman, "Rural Labour in the Bombay Textile Industry and the Articulation of Modes of Organisation", in Peter Robb (ed.), Rural South Asia. Linkages, Change and Development (London, 1983), p. 141.

is Premchand, "Jurmana", Kafan, February 1959. 
the countryside, to fill up emergency shortfalls by keeping a pool of substitute labor at hand [badlis] and they helped the mills to maintain order among the workers. In Delhi, the sanitation Jamadars did not come from among the rank and file of the sweepers. In the 1870 s, some sweepers were promoted to the rank of Jamadar, but in 1888 the DMC decided to hire "some other caste but sweepers". Thereafter, the DMC appointed "literate military pensioners" to the position of Jamadars in all the city's wards, believing that the ex-army people might have a "natural" command over their underlings. The point here was to distinguish the sweepers from their overseers, to create a feeling of separation and distance between labor and their overseers, however close their class/caste positions. To increase the distance, the Jamadars who did not rise from the ranks of the sweepers wore a badge. ${ }^{60}$

The DMC gave the Jamadars a series of tasks which enabled them to exert absolute authority over the sweepers and to create an entrenched patronage system in their favor. They hired and fired sweepers, as well as oversaw the lives and labors of the sweepers on the municipality's behalf. To enter the municipal sanitation service, the Mehtars paid dasturi, a fee or commission to the Jamadar (in collaboration with the Sanitary Inspector who took his cut in the process); this fee was a considerable amount coming to twice a month's salary in $1933 .{ }^{67}$ Why did the sweepers pay such a steep mortgage on their future salary to enter the service? The answer to this question illustrates the social costs borne by the sweepers for the sake of the system's "efficiency". The sweepers paid for coveted full-time jobs, since these were being denuded in favor of part-time jobs which enabled the system to follow its norms of efficiency. One full-time sweeper attended six lanes, a task which occupied the sweeper until 3 p.m. as a result of which residents complained that their streets remained dirty through the day. Two half-time sweepers, on the other hand, worked three lanes each and finished them by the end of the morning. The same work could be done faster for the price of one sweeper. In 1929, two-thirds of the sweepers worked half-time for Rs. 6 per mensem, less than half the salary of a full-time worker (Rs. 13 per mensem). To make a living the sweepers held two or more jobs, being unable to sustain themselves on the municipal "salary". If not part-time work, the sweepers worried about being released in slow seasons. The DMC hired 75 per cent more sweepers in the winter than in the summer (when the bureaucracy went off to cool down in Shimla). ${ }^{68}$ To secure precious full-time or any work, the sweepers mortgaged a few months' salary to the Jamadar, a small price to pay for a viable salary. The pressures on the sweepers came out in

of DMC Progs., 5 September 1887; DMC Progs., 1 October 1888.

67 Mahadev Desai, "A Quarter in New Delhi", Harijan, 15 April 1933.

os DMC Progs., Special Meeting, 27 August 1929. 
their closely bound relationship with their jobber, who found them work, for a tidy fee.

The colonial officials appreciated the work of the Jamadar in securing them labor at such easy rates. They did, however, express concern over their lack of direct control over the workers; they also considered the quality of the workforce given its impermanency and that it bore the thumbprint of the Jamadar and not a European "missionary of sanitation". The question of maintaining the sanitary state of the city, we are told in 1927, "more than counter-balances any apparent economy that may result" from retaining the part-time system. The part-time system enabled the municipality to do the cleaning quicker (i.e. before noon) by paying less than one full-time salary to two part-time sweepers, but it was deemed "impossible" to keep these part-time sweepers "as well disciplined and alive to their responsibilities as is practicable in the case of the whole time employees". 69 This concern was not acted upon given the municipality's reliance upon parochial notions of commercial efficiency to determine their policy. For the colonial bureaucracy, the issue of the impoverished lives of the sweepers boiled down to the question of municipal control over labor; in an inquiry in 1926, for instance, the report concluded a discussion on the "rights" of sweepers with the statement that it was "essential that [the sweepers] should all be Municipal sweepers otherwise there is no control over them". Since the DMC principally wanted control, they relied upon the Jamadars to exert the requisite authority.

The Jamadars not only had the right to hire sweepers, but they also fined and fired them. The Jamadar imposed all sorts of levies on the sweepers' already meager salaries; if the sweepers did not pay these "dues", the jobber reported them to the Sanitary Inspector for not doing their work properly or for being negligent in attendance. In 1933, the dues (or bribes/rishwwat) ran to Re. 1 from a full-time salary of Rs. 13 (we do not know if this due is halved for part-time or if the due is standard). The sweepers, we are told, dare not "displease their Daroga by non-payment [of the dues], otherwise he may throw them out of employment on the least pretext". ${ }^{70}$ Given the lack of permanency of service and the insecurities associated with the capriciousness of the Jamadar, sweepers understood that they could be "discharged at any time without notice". This was not an arbitrary and unofficial rule, a native continuity which slipped under the fabric of modernity, for in 1912 the Government of India decreed that the Health Officer can "appoint, dismiss or suspend any of the menial servants of the Sanitation Department drawing a salary of Rs. 10 or under". This included all the

60 Delhi State Archives [DSA], Chief Commissioner (Education), B Progs., 6(7), 1927; DSA, Chief Commissioner (Education), B Progs., 5(7), 1926.

70 A.V. Thakkar, "Sweeper by Choice", Harijan, 1 April 1933. 
sweepers, beldars, carters, and others who worked under the Jamadar. In sum, Amritlal Thakkar rightly pointed out in 1937 that the "sweepers are always at the mercy of their Jamadars and are therefore compelled to bribe them even for small mercies and even for ordinary rights". ${ }^{71}$ For Gandhians such as Thakkar the "rights" which they wanted to see the sweepers enjoy included such socialist staples as privilege and casual leave, provident fund, holidays on periodic days, a cost of living increase and fixed hours of work. Where the Gandhians faltered was in their lack of a clear analysis of the reasons why the sweepers did not enjoy these rights. In a classic liberal formulation, Mahadev Desai threw up his pen with the question, "why should these sweepers be cheated of these elementary rights?"rz One can almost hear the colonial official smile.

With the wages at a low level and with the Jamadar as demanding as ever, the sweepers invariably went into debt. The debt crisis benefited the Jamadar who along with Pathans and Mahajans lent money to the sweepers at exorbitant rates of interest and perpetuated their terror and awesomeness. ${ }^{73}$ The sweepers did not spend unusual amounts on non-utilitarian ceremonies and social occasions; their debt came from their inability to sustain themselves. Take the budget of Kallu's family in 1933. Both Kallu and his wife earned Rs. 23, from which Rs. 2 went to the Sanitary Inspector and Re. 1 to the Jamadar. Kallu borrowed money during the year to pay for an illness, and he owed an interest payment of Rs. 11. Of the remaining Rs. 9, the family paid their rent (Rs. 3), purchased flour (Rs. 4), pulses, meat, vegetables, spices, salt, fuel, oil and soap (about Rs. 2). Then the family spent a rupee on tobacco and two rupees on liquor (consumed about once or twice a month). In the context of the family's earnings and of the budget, the high price of liquor stands out and consequentially, "the liquor shop men have a feeling that the pay of the scavengers stands mortgaged to them". ${ }^{74}$ The family incurred a deficit of Rs. 4 per mensem, a debt which we are told "is handed down from generation to generation". In 1933, no sweeper owed less than Rs. 300 and some moneylenders used creative interest rates on small principles to show in their books that the sweepers owed them up to Rs. $1,500 !^{76}$

The municipality justified the low wages using two arguments. First, they argued that there is "seldom distress" among the sweepers. "True,

"1 A.V. Thakkar, "The Plight of the Sweepers", Hindu (Delhi), 13 September 1937.

$n$ Desai, "A Quarter".

"3 Ibid.; NAI, Education (Sanitary), A Progs., February 1913, nos 49-50.

"C. Rajagopalachari, "Municipal Sweepers", Young India, 12 November 1931.

"s Sivanarayan Tandon, "The Food They Take and Their Way of Living", Harijan, 26 August 1933.

76 Sheonarain Tandon, "The Problem of Indebtedness", Harijan, 23 September 1933; N.R. Malkani, "A Promising Experiment", Harijan, 9 September 1933. 
their incomes are small, but then their wants are few." In order to absolve themselves from culpability on the score of the poor living conditions of the sweepers, the colonial bureaucrats argued that "the squalor of their surroundings is due far more to ignorance and want of civilization than to want of means"." This was not in good faith, given the recalcitrance of the colonial authorities to improve conditions for the sweepers. Gandhi's Harijan Sevak Sangh reported that "months of irritating and futile correspondence have won a tap or two for some dry and dirty basti". "The cold; callous and criminal negligence of the employees of the municipalities and other public bodies" make the sweepers endure terrible conditions. To prevent addressing the issues, the DMC "learnt the fine art of transforming the fixing of a water-tap or an electric light into a second class communal question in the heat of which the authorities can bask in comfort and write reports". ${ }^{78}$ Reading these sympathetic attempts by the Gandhians to improve the living conditions of the low caste sweepers, I am reminded of the Balmiki man who led me into Sau Quarters in Karol Bagh in 1992 and pointing to the animal refuse all over the narrow streets, said: "all this is the property (jaydad) of the municipality". ${ }^{79}$

The second argument for sweepers not needing "family wages" was that their women and children also worked to bring money into the family unit. Sweepers, the Chief Commissioner wrote in 1916, stand at the bottom of the social scale, but "they are not in a material sense by any means the poorest part of the population". That "they can rely on the assistance of their women and to some extent their children [...] places them in an unusually favourable position as wage earners". 80 In 1911,795 women worked as sweepers for every 1,000 men $(5,403$ women; 6,792 men). In 1921, 667 women worked as sweepers for 1,000 men, and in 1931, 642 women worked as sweepers for every 1,000 men. $^{81}$ The fluctuations are not significant and we can assume that about three women worked as sweepers for every five men. In 1929, a municipal document tells us that only 228.4 women worked as full-time municipal sweepers for every 1,000 men. ${ }^{82}$ Census data which we used above, therefore, must include both part-time and full-time sweepers. We know that certain municipal jobs, such as drivers, carters, Jamadars and sewage clearers, were reserved exclusively for men. Women were hired into full-time service in the cases where the municipality hired husbands and

n District Gazetteer Delhi, 1912, p. 139.

${ }^{78}$ Annual Report, Harijan Sevak Sangh, 1932-1933, p. 10 and Anmual Report, Harijan Sevak Sangh, 1933-1934, p. 11.

* Raju Kumar, Sau Quarters, Delhi, 18 January 1992.

- DSA, CC (Home), B Progs. no. 169, 1916, letter by Hailey on 30 May 1916.

"Census of India, 1911, vol. XIV, pt. 2 Tables, Table XV pt. A; Census of India, 1921, vol. XV, pt. I Report, p. 363; Census of India, 1931, vol. XVI, ch. VIII.

- DMC Progs., Executive \& Finance Sub-Committec, 23 March 1929. 
wives as teams to attend to public conveniences for twenty-four hours. The municipality built a hut next to the facilities and the couple lived there and cleaned "the latrines at all hours as one of them can stay during the absence of the other". ${ }^{83}$

Women worked mostly as part-time street sweepers or as domestic servants. By 1965, we are told that "by custom the male has begun to think that scavenging is a woman's job". Here "scavenging" refers to working in private homes and removing refuse to the municipal dump. Most municipal sweepers were men, but women also participated in the workforce to complete the circuit of refuse from house to dump. ${ }^{84}$ Whether these women were wives of the sweepers or not is not our concern here, for we wanted to show that even within the municipality's logic it was not until 1970 that the actual percentage of municipal workers was divided evenly between men and women. ${ }^{85}$ The municipalization of women in menial jobs, however, does not serve as an adequate justification for low wages for menial labor.

\section{DOCILE COMMUNITY}

Given the difficult conditions in the labor process, why was there no institutionalization of resistance alongside the institutional integration of the DMC's sanitary regime? From the defeat of the sweepers in 1889 until the formation of trade unions in the late 1930s, the sweepers did not protest against their lot collectively. If organization at the workplace was difficult because of the Jamadar and the very nature of sweeping (spread out over the entire cityscape), why did the sweepers not organize in their neighborhoods? Working classes rely upon neighborhoods as an indispensable base for organization and to sustain the workers during strikes. In their neighborhoods, the workers come together to share their feelings about work on the shop-floor and the trials of life in general. The shop-floor helps the workers formulate the immediate goals of their politics (i.e. higher wages, better work and living conditions), and this form of activity provides the means towards a greater politicization of the working class, a way to introduce workers to philosophies of daily life which are already embedded in their common sense. Delhi sweepers shared neither a shop-floor nor neighborhoods.

In 1916, the colonial authorities put into effect a plan to settle most low caste communities into the Western Extension Area (WEA), west of the walled city. The "ghetto" allowed the colonial regime to monitor

* DSA, CC (Education), B Progs. no. 6(15), 1928; DSA, CC (Education), B Progs., no. 4(31), 1931; DSA, DC files, no. 49, 1938.

* N.R. Malkani, Clean People in an Unclean Country (Delhi, 1965), p. 99.

s Malavika Karlekar, Poverty and Women's Work. A Study of Siveeper Women in Delhi (Delhi, 1982), p. 49 and Mary Searle-Chatterjee, Reversible Sex-Roles. The Special Cases of Benares Siveepers (Oxford, 1982), p. 35. 
the low castes in substandard living conditions. The walled city was congested and the "offensive trades" needed to be moved out of its environs. Rather than allow many slums to dot the walled city, the administration provided one area to localize the trades (such as leatherwork, lime burning, pottery, animal slaughter) and the poor population. ${ }^{86}$. Until the late 1930s, the sweepers were not allotted housing in this new development.

- The sweepers lived in neighborhoods spread over the cityscape, some having just one family unit and others up to ten units. The logic for this arrangement stemmed from the process of refuse removal. The sweepers, one document tells us, should in the "interest of efficiency" live somewhere in the locality where they worked. ${ }^{87}$ The municipality hired husbands and wives as couples to take care of a latrine and secure cleaning of the latrine at all hours as one manned the post during the absence of the other. These latrines were all over the city, and they account for the single family units spread over the walled city and its suburbs. Larger groups of sweepers lived next to dumps and to refuse works, since it meant that they could be brought to work at any time and also that the land upon which they lived was not worth more than the land of the dump..$^{88}$ The imperatives of the process of refuse removal prevented the mobilization of the kind of neighborhood solidarity which developed (for instance) among the Chamars of Delhi. It was only after the 1930s that the sweepers lived in identifiable areas, although these neighborhoods were spread out over the entire city.

If the sweepers did not have the neighborhoods to give them an indispensable base for politicization, this does not mean that they did not develop any sense of community or of community politics. ${ }^{89}$ Pahalwani [wrestling] in akharas was one of the modes of interaction for the male Mehtars, who met at their wrestling pits to test their strength. It is easy to disregard all the talk of the strength of the Mehtars from the mouths of the living elders, only to pass it off as revisionist machismo. It is that, or partly that, but it is also a "racial" fiction to counter the prevalent understanding that low castes are feeble of mind and body. The elders do not only remember the toughness of individual bodies (this wrestler or that wrestler), but also the memories of a community

* NAI, Education (Municipalities), A Progs., March 1916, nos 17-18; NAI, Education (Municipalities), A Progs., February 1917, nos 3-8.

7 DSA, CC (Edueation), B Progs., no. 4(64), 1936.

* DSA, CC (Education), B Progs., no. 40, 1914; DSA, DC Progs., no. 33, 1930; DSA, CC (Education), B Progs., no. 4(31), 1931; DSA, CC (Education), B Progs., no. 4(114), 1932; DSA, CC (Education), B Progs., no. 4(139), 1932. On the cost of the land, sec A.P. Hume, Report on the Relief of Congestion in Delhi, vol. I (Simla, 1936), pp. 38-39. 29 Because of strict regulations about marrying outside their gotra, the untouchables retained links with other low castes from far afield. See R.S. Sandhu, "Rites de Passage of some Scheduled Castes: II. Marriage Rites", Eastern Anthropologist, 34, 2 (April-June 1981). 
power. "There was a time", Faqir Chand told me on the roof of his house one evening in Pahargunj in March 1993, "when we used to hold our own in Delhi against all the other communities (qaum)." It is with much pride, the swelling of his chest, the wistfulness in his eyes that he called his community a "martial qaum". "Kasrat karo aur tagre raho" was the motto of the young men, exercise and remain strong. The Mehtars moved from akhara to akhara, from wrestling pit to wrestling pit, testing their strength and meeting their friends and kin. Baru Pahalwan, Bunno Pahalwan, Raghu Pahalwan, these are the names which bring back memories of a fictive power which was nonetheless real. In the story of Keer Singh, the collective imaginary of the Balmiki men of today resonates with the real effects of this strength. Keer Singh's father, Chowdhry Bondhu, borrowed money from a sahukar [moneylender] of Teli Mandi called Bhasheswar. The amount was between Rs. 500 and Rs. 1,000, a large amount in the early 1930s. Although we do not have details of the debt, we can appreciate the moneylender's historical alchemy with figures. The Chowdhry could not pay back the sahukar, who came and cursed the Chowdhry using language which insulted the man's caste. Incensed, the son, Keer Singh, went and killed the sahukar. Keer Singh was sentenced to death, but on the intercession of the sweeper who worked in the English Judges' house and a group of Mehtar elders, he was sent to the Andamans (a penal colony). The pleaders, I was told not without pride, did not plead the boy's innocence, since he killed the sahukar and vindicated the insult to the community.

While the more physical men met in their various akharas to wrestle, other men, women and children took advantage of their kinship ties across the space of the city to pay visits on each other as well as to help each other with domestic and ritual events. Sunheri Devi remembered her trips into the walled city, to meet and eat with kin and friends. "We were not from one family (khandan)", she said, "but it felt just like we were." Meetings were essential, but they were sporadic and inconstant. Days went by without any connection, for the distances in those days between neighborhoods was great indeed. Births, weddings, deaths, festivals and other institutionalized reasons to gather did not come very often. Twice a year, on the fifth days of Asauj and Chait, the Mehtars gathered for about six hours on Karnal Road from Lahori Gate to Subzimandi for a fair which was also "an occasion of religious worship to people of low castes, such as sweepers, who carry penuous made of sticks and rags in honour of their Pir".90 These occasions, however, had reasons for their own existence and the elders could not recall any political activity at them. These fleeting contacts did not provide an indispensable base for socio-political action which was (in

${ }^{\circ}$ DG Delhi, 1883-1884, p. 62. 
many ways) necessary for trade union and political activity. Without neighborhoods, the task of mobilization was not impossible, but difficult.

Further disruption in the short term came from the immigration of untouchable Chuhras to the city since the DMC hired most of them into the sanitation service. Immigration into a tight labor market normally provokes a struggle between the communities of laborers, but in the case of Delhi, which was a wide-open labor market, the incoming Chuhras had little trouble finding work as sweepers. When Delhi became the capital of British India in 1911, the city expanded so much that the city needed more sweepers. The DMC understood that the migrant workers were perfect for their newly rationalized department because they did not have an emotional connection with the history of struggle between workers and the DMC, a struggle which was only a generation outside the memory of the Mehtars. Without such a connection, the real value of the limited rights which they were entitled to was not easily known and was not appreciated. To top it all, because of their interactions with the seemingly overwhelming power of the Jamadar, they might be terrorized by him to stay within the limits set by the DMC.91 "It has been found by experience", a municipal report of 1927 informs us, "the outside sweepers are better workers than these in the city", since the "outside workers" came to the city in awe of the wonder and wages of urban life. ${ }^{92}$ Of course, these wonderful wages were only wonderful in terms of the aggregate income and not in terms of earnings per capita in real terms. For the new migrant, however, in the flush of having found work after being pushed off the land in the Punjab and western Uttar Pradesh, the initial wages seemed to be more than adequate. In a sense, the relationship between the Mehtars and Chuhras was not one between workers and "scabs", since the labor market was not tight. Nevertheless, the arrival of the Chuhras in the city delayed any community formation among Delhi sweepers as the migrants retained ties and bonds with their home villages.

\section{CONCLUSION}

The extra-economic coercion and the overwhelming experience of power at the lowest level of organization reintroduces a question which Dipesh Chakrabarty dealt with at length: why does capitalism which proclaims

91 Omvedt tells us that the Jamadars worked with the rural gentry to send surplus labor to the cities, a practice which introduced the Jamadar to another circuit of power making him seem all the more powerful, see Gail Omvedt, "Migration in Colonial India: The Articulation of Feudalism and Capitalism by the Colonial State", JPS, 7 (1980), pp. 192195.

92 Report on the Administration of Delhi Municipality, 1926-1927, vol. II (Delhi, 1927), p. 34; DSA, CC (Education), B Progs., no. 6(7), 1927. 
the advent of the modern age encourage these "prehistoric" practices? Chakrabarty argues that the Sardar (the Jamadar) saved the capitalist "the expense of investing in institutions otherwise typical of the capitalist control of labor. Sardari control was cheaper than housing, health care or an articulated body of rules guiding the conditions of work." ${ }^{93}$ These "savings" worked in the interests of the municipality who got their work done cheaply at the expense of labor whom they did not care to see (the municipality did not generate even one report on the living and laboring conditions of the sweepers). The workers were expected completely to assume the cost of reproducing labor-power, which they did with the support of their families. The Mehtars' web of social relations became the resource from which they struggled to sustain themselves, their families and their communities. Bourgeois social relations ended at the level of the Jamadar or at the level of the contractor; beneath that lay an authoritarian structure which attempted to draw absolute surplus labor from the low castes. Colonial officialdom, for whom efficiency was measured in terms of time and work discipline as well as the ratio of commercial return from the labor process, sought to discipline labor in order to constitute an efficient urban order. The rationality of colonial officialdom was an ends-based one, in that its primary interest was to remove the refuse from the city with the least possible expenditure. In order to fulfill this, exploitative practices such as contract labor and the role of the Jamadar were institutionalized; the laborers and the concrete laboring practices became irrelevant as long as the work was done.

The logic of capital cannot be seen in its pureness, for it is always already coded in a culture. The culture of "capital" is based upon the notion of equality. The culture of "capital" in the colonies is not imperfect, but it has its own colonial cultural history. In this essay, and drawing from the work of Dipesh Chakrabarty, I have argued that the "logic of capital" in the colonies emerges out of its own cultural framework, which is systematic inequality through a Manichean division of society into the colonial rulers and the colonized subjects. This cultural presupposition produces a logic of capital and of power which is its own and which then gives rise to a different form of working-class consciousness. This essay is a reflection on the troubles of that "working class" and of its attempt to make and unmake itself.

The narrated history, in turn, makes it difficult to conceptualize of the sweeper or the system of sanitation in India as a natural barrier to the logic of capital. ${ }^{9}$ For the Indian sweeper is precisely a product of

93 Chakrabarty, Rethinking, p. 107.

Cf. Syed Hussain Alatas: "The ideology of colonial capitalism evaluated people according to their utility in their production system and profit level. If a community did not engage in activities directly connected with the colonial capitalist venture, the community was 
capital's logic, which finds its barrier in itself rather than externally in any cultural or racial logic. If capital posits "tradition" as a barrier which it must get beyond, it is only able to do so ideally. ${ }^{95}$ In reality, "tradition" remains as the mainstay of colonial capital and the colonial state. The national-state after 1947 introduced an element of liberalism to confront the inequities of the social order but, apart from token reforms, the Delhi administration continues to rely upon Jamadars and contract labor, the twin pillars of sanitation on the cheap with sweepers bearing the marks of capital.

spoken of in negative terms." The image of the lazy native was "a major justification for territorial conquest, since the degraded image of the native was basic to colonial ideology". The Myth of the Lazy Native (London, 1977), pp. 212-213.

os Karl Marx, Grundrisse (New York, 1973), p. 410. 